\title{
Nissens udviklingshistorie: Da Gårdboen blev hyggelig
}

Et casestudie affamilier med børnehavebørn viser, hvordan nissen har andret sigfra
den landbrugsbundne sagnnisse til børnenes julenisse anno 2016 .

af stud.mag. Niels Peder Pedersen, Syddansk Universitet

S

om universitetspraktikant ved Dansk Folkemindesamling på Det Kgl. Bibliotek foretog jeg hen over julen 2016 et casestudie af nisser hos moderne børnehavebørn. Undersøgelsen foretoges i tre børnehaver på Vestsjælland og havde to dele: Den første var et spørgeskema til forældrene, der fokuserede på, hvilke traditioner de udførte i hjemmet og hvorfor. Den anden var interviews med pædagogerne for at klarlægge børnehavens nissetraditioner, samt børnenes forhold til dem. Pædagogerne blev interviewet som repræsentanter for deres respektive institution. Gennem mine besøg i børnehaverne fik jeg også mulighed for at tale med nogle af børnene og skabe mig et indtryk af, hvad deres forhold til nissen var. Med udgangspunkt i dette casestudie vil jeg i denne artikel vise, hvordan nissen har udviklet sig fra den husgud, vi kender fra sagnene, til den moderne børneven, som mange familier har til jul.

Men før vi kan se hvordan nissen har ændret sig, må vi først dykke ned i hvordan han var i sagntiden.

\section{Sagnnissen}

Det er ikke til at sige, præcis hvor gammel nissen er. Ordet kan med sikkerhed spores tilbage til 1587, ${ }^{1}$ og lignende væsner under andre navne kendes helt tilbage til hedensk tid. Disse henvisninger er dog typisk spredte og vage. Det meste af det, vi ved om nissen, stammer fra folkemin- desamlernes arbejde i 1800-tallet, hvilket egentlig er paradoksalt, idet nissen på dette tidspunkt var på retræte: det bondeliv, som var præmissen for dens eksistens, udviklede sig markant i takt med de samfundsændringer, industrialiseringen bragte med sig. Men nissen var på dette tidspunkt en anden end den julenisse vi kender i dag.

Sagnnissen, eller 'gårdboen', var en lille fyr på størrelse med et ti-tolv års barn. Han var iklædt den samme røde hue og grå kofte som de bønder, han levede iblandt. Han havde ofte langt skæg, og så var han betydeligt stærkere, end hvad hans størrelse indikerede. Nissen boede typisk på høloftet over laden, og det var også i og omkring laden, at han havde det meste af sit virke. Det var også her, man typisk så ham; nissen var nemlig altid en 'ham': En lille, men gammel mand uden kone eller børn.

Nissen stod i et særligt forhold til de store kreaturer, hestene i særdeleshed, og han passede dem nænsomt. Et af de tidligst nedskrevne sagn om nissen fortæller om dette særlige forhold mellem hest og nisse. Det lyder således:

I Tirup boede en mand, som havde en dejlig hvid hoppe, der i mange år var gået $i$ arv fra far til søn. Denne hoppe holdt nissen meget af, og han bragte lykke og velstand til gården. Han bragte også megen både tærsket og utærsket sæd med fra naboens lade. Han passede 


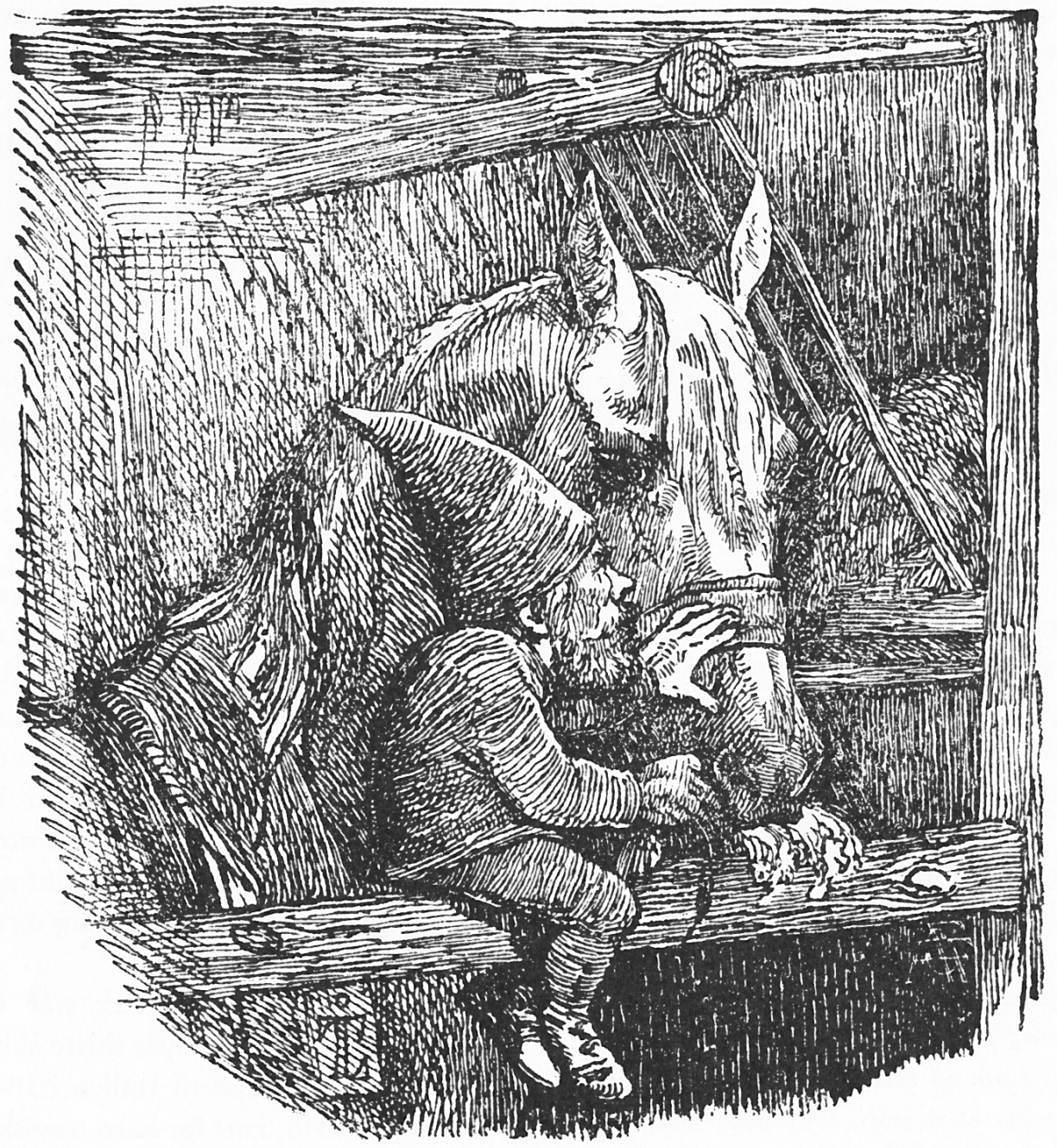

J.Th. Lundbye: "Nissen i Tirup." Illustrationen er skabt til Flinchs Almanak 1842. Billedet viser nissen og hans elskede hvide hoppe, som de fremstär i J.M. Thieles Danske Folkesagn fra 1818-1823. Dette er en af de forste nisseillustrationer, som bliver almenkendt i den danske befolkning, og dens skaber bliver en af de store nissekunstnere i ärene der folger.

hoppen, fodrede den om natten, og brød sig ikke om at den blev brugt til arbejde overhovedet.

$\mathrm{Nu}$ hændte der det, at gården overgik til en ny ejermand, og denne havde ikke meget tiltro til de ting, han fik fortalt om nissen. Derfor solgte han den hvide hoppe til sin fattige nabo. Nu gik der ikke længe, førend det var den fattige nabo, som havde lykken med sig. Imens måtte 
den før så velstående gårds ejer se til, mens tingene gik dårligere og dårligere for ham. Hvis så den nye ejer af hoppen kunne have været tilfreds med sin velstand, så havde hans efterkommere nok været velstående den dag i dag. Men da han havde set den megen sæd, som hver nat kom til hans lade, ønskede han også at se nissen, som bragte den. Han gemte sig en nat og så også nissen komme med en sæk korn fra naboens lade. Men da nissen mærkede, at han var der, gav han sig sørgmodigt til at fodre og strigle hesten en sidste gang. Så vendte han sig mod det sted, hvor manden lå, og sagde ham farvel. Fra den tid af blev begge naboer lige velstående, da hver nu beholdt sit eget korn. ${ }^{2}$

Dette sagn vidner både om nissens forhold til hestene, men også om at nisser nødigt vil ses af mennesker. Nissen foretrækker at gøre sit arbejde i det skjulte, når det er muligt.

Udover at fodre, strigle og passe hestene, havde nissen også andre arbejdsopgaver på gården. Han hjalp f.eks. gerne med tærskningen og høsten. Et sagn fortæller om, hvordan en bonde havde en mark og hvert år ved høsttid gik ud med et stort fad grød og noget god øl. Dette satte han på en sten og gik igen. Næste morgen, når han kom igen, var marken høstet, kornet sat i traver, og øl og grød fortæret. Et år fik hans kone, som var grumme nysgerrig for at vide, hvordan dette gik til, lov at gå ud med forplejningen. Men i stedet for at forlade stedet i stilhed, som hun skulle, gemte hun sig for at observere, hvad der skete. Hun så da tre små mænd med røde huer komme og sætte sig for at spise grøden og drikke øllet. Dette gik i en rivende fart, og snart var de færdige med maden, da gik de i gang med arbejdet; dette gik ligeledes i en rivende fart. Den første mand høstede kornet, den anden samlede det og bandt det i neg, og den tredje samlede negene i traver. De var hurtigt færdige med arbejdet, og da konen så hvor hurtigt det var gået, udbrød hun, at når de sådan kunne arbejde, så skulle de nok også få en ordentlig forplejning. Men da de små mænd hørte hende, forsvandt de. Uanset hvor mange gange man siden prøvede at sætte grød og øl frem til dem, fik bonden aldrig igen høstet marken på dén facon.

$\mathrm{I}$ dette sagn ser vi nissen, som han ofte fremstår i sin professionelle kapacitet: En yderst effektiv arbejder, som i løn får sin sødegrød, og til tider også noget god øl. Sødegrøden er et af de mest gennemgående træk ved nissen. Om det er på ris eller byggryn kan variere fra sagn til sagn. Det er dog altid sødgrød, og ikke den vandgrød, som gårdens folk selv fik til hverdag. Det varierer, hvor ofte nissen forventer sin grød; nogle gange er det hver aften, andre hver lørdag, eller også så sjældent som ved højtiderne; jul, påske og pinse. Da nissen anser grøden for sin ret, bliver han vred, når han ikke får den, eller når den ikke er af den kvalitet, som han forventer. Så ophører han med at passe sit job eller hævner ligefrem den uretfærdige behandling. Dette er der talrige eksempler på: piger eller karle som, for at drille nissen, har hældt grus i grøden eller gemt den påkrævede smørklat for ham. Det varierer dog, hvor stærkt nissen reagerer: Fra det simple - at nissen trækker ugerningsmændene op og ned i sengen hele natten, således at de ingen søvn får - til det mere farlige; at han lægger dem på et bræt over den åbne brønd, så de får en slem forskrækkelse, når de vågner.

Et velkendt og udbredt sagn fortæller, at pigen i misundelse over den gode 
grød, som nissen fik, en aften for at drille ham havde lagt smørklatten på bunden af fadet i stedet for oven på grøden. Da nissen sætter sig til grøden og ikke kan finde smørret, bliver han ude af sig selv af raseri, og i arrigskab drejer han halsen om på bondens bedste røde ko. Da hans vrede således er blevet tilfredsstillet, sætter han sig til sin grød igen. Da opdager han smørret på bunden af fadet og angrer sin uberettigede hævn. Han grubler, om ikke han kan gøre skaden god igen og husker da, at der på en gård et stykke væk står en ko ganske magen til den døde. I ly af natten begiver nissen sig med den døde ko på ryggen over landet til nabogården. Her udskifter han de to køer og begiver sig hjem med den levende ko. Næste morgen undrer pigen sig over at koen kvier sig sådan ved at blive malket af hende, men ingen opdagede nogensinde, hvad nissen havde bedrevet i løbet af natten.

Sådan er nissen ofte, han har et iltert temperament, og han er ikke den, som bruger lang tid på at overveje, men reagerer stærkt og direkte mod den, der har forarget ham. Selvom det i dette sagn ikke er koen, som har snydt ham for hans smør, er der alligevel en sammenhæng: Når nissen således snydes for sin løn i form af grøden, tager han sin hævn ved at tage sit arbejde igen. I denne sammenhæng må man forstå, at det er nissens fortjeneste, at koen er stor og fed. Nissen er altså ikke urimelig, han er derimod meget reel. Det er også derfor han godtgør den uret, han har gjort bonden, da han opdager, at han har fået sin smørklat. Vel er tyveri ikke velset, men for nisser gælder andre regler: Det er således endog ganske udbredt, at nissen stjæler foder fra nabogården, hvis hans egen gård mangler. Selv her er der dog en vis rimelighed i hans adfærd, for nissen stjæler kun fra de gårde, som har foder nok. Så på sin egen facon kerer nissen sig meget om ret og rimelighed, og han gengælder såvel gode som slette gerninger.

\section{Julenissens opståen}

Nisselignende væsner fandtes $\mathrm{i}$ landbosamfundene i hele Europa, omend under andre navne. De lignede typisk også nissen af udseende; de var små og bar ofte det samme tøj som de bønder, de boede og arbejdede hos. H.F. Feilberg beskriver disse nisselignende væsner som husvatter i sin bog om nisser. Feilberg var folkemindeforsker og indsamler, og han skrev i 1919 Nissens Historie. Bogen er udgivet regelmæssigt siden og kan stadig købes. Feilberg bruger ordet "vætte" til at henvise til ethvert overnaturligt væsen, hvad enten det er ellefolk, nisser eller trolde. Med husvatte mener Feilberg et væsen, som beskytter huset. Dette ligger tæt op af begrebet "husgud" - den lille forskel består i, om væsnet betragtes som en gud. Husguder har typisk også altre og små gudefigurer, som man ofrer til, men det har husvætterne ikke. Det er ikke usandsynligt, at denne forskel skyldes at husvætterne har måttet tilpasse sig kristne samfund, hvor afgudsdyrkelse og gudebilleder var strengt forbudt.

Nissen havde altid eksisteret i mere eller mindre samme form blandt jordbrugere, indtil en anden gruppe fattede interesse for den. Skellet kan omtrentligt sættes til nationalstatens fødsel og den efterfølgende higen efter national identitet. For at finde frem til den sande $-\mathrm{i}$ dette tilfælde - danske identitet, vendte borgerskabet og kunstnerne sig mod de mennesker, som levede allermest isoleret fra kulturpåvirkninger udefra: bønderne. 


\section{Cn Risfe.}

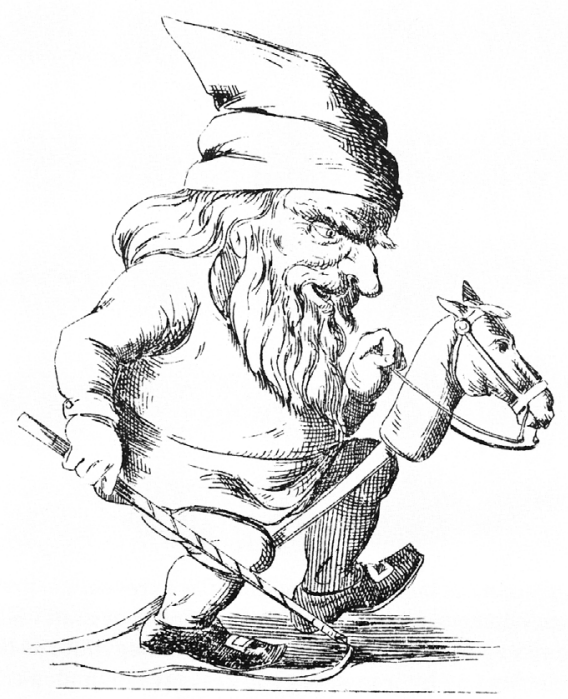

Bas nu paa, গisje graa,

Mled fin robe 5 fue,

ßaa fin Fux

Den lifle $\mathfrak{R u r}$

Riber int i sulejtue.

\section{Con Migféne.}

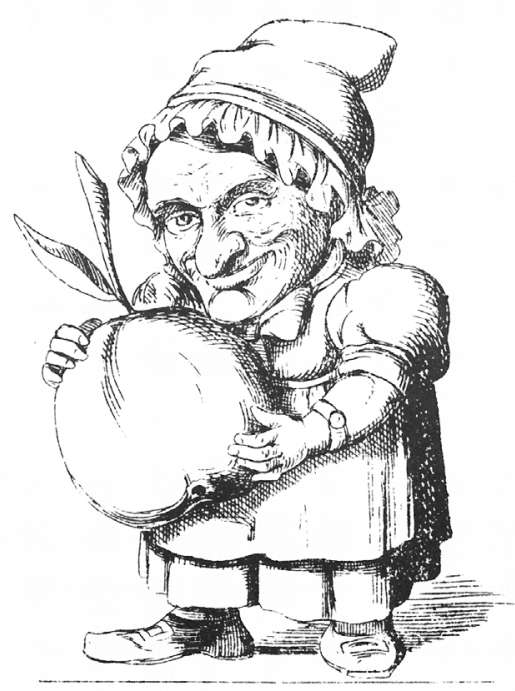

2(s) blex byre ex' inar, Det Du viftuot veed, Derfor iffun eet Du farer, Blitu mu iffe tred

Nisseparret er fra et julehafte med rimgåder, som også er nissekonens debut. Op til dette tidspunkt havde nisser altid varet ugifte mand, men i takt med at julenissen bliver en del af borgerskabets jul, bliver den ogsa en spejling af selvsamme borgerskabs normer, og den fär derfor en kone. Dette ses også $i$ den tilhørende gåde: "Husker du den lille, du nylig gatted" på, med rode hue og med kofte grå? Han er fulgt med tiden og den gode tone, og har sig nu en lille ..." Kvindelige nisser har veret udbredte siden.

I Tyskland blev brødrene Grimms eventyrsamling født af en søgen efter den tyske folkesjæl; i Danmark indsamlede folkemindepionerer også eventyr, sange og sagn blandt bønderne, og de gjorde borgerskabet bekendt med deres fund. Samtidig var 1800-tallets borgerskab i gang med at genopfinde julen: Man havde importeret både juletræ og julesangstraditioner i årene før, og træet blev hurtigt et midtpunkt i den 'nye' jul. På samme tidspunkt var der i Rom en dansk kunstnerenklave, og da denne holdt sin julefejring i 1836, blev der pyntet op med 'nisseklip'. Begivenheden er det tidligst kendte eksempel på, at nissen forbindes med julen: maleren Constantin Hansen klippede papirnisser til at pynte sit atelier med, og arkitekten Gottlieb Bindesbøll skrev efterfølgende hjem til sin bror, den 
senere biskop Severin Bindesbøll, om begivenheden. Da beretningen blev trykt i Dansk Kunstblad, spredtes ideen langt uden for den lille kunstnerenklave.

Nissen bar tanken hen på gamle traditioner og danskhed, og den passede derfor perfekt ind i den nye jul. Med tiden blev nissen oftere og oftere kodet kunstnerisk sammen med julen, og gradvist blev nissen en uundværlig del af den. Vi begynder at se den i skønlitteraturen, f.eks. i H.C. Andersens Nissen hos Spakbøkeren og i Niels Holgersens Fantastiske Rejse samt Ved Nytärs Tid i Nodebo Prestegaird, hvori udtrykket 'julenisse' bliver brugt for første gang. Allerede fra Constantin Hansens papirklip bliver nissen fremstillet som en gavebringer, og dette element bliver en central del af julenissens natur helt frem til i dag. Det medfører en smule forvirring, da julemanden så kommer til landet i første halvdel af 1900-tallet, for julemanden bringer jo også gaver til børnene, og på klæder og farver ligner de hinanden en del. Der kommer aldrig nogen endelig afklaring af forholdet mellem julemand og julenisser; om julemanden er en nisse, eller om nisserne hjælper ham. De lærer dog at leve sammen i den danske jul alligevel.

Efter at julenissen er blevet et etableret julesymbol, bliver den en stærk del af julefortællingerne. Både i litteraturen, $i$ radioen og i fjernsynets julekalendere er der en stadigt voksende verden af nisser.

\section{Nye traditioner: Brugen af nissedøre}

Det er dog ikke tilstrækkeligt at skelne mellem sagnnisser og julenisser, som de så ud omkring år 1900: Mange forandringer er sket siden da, og der kommer hele tiden nye praksisser til, som igen kaster nye forestillinger af sig.
I december 2016 foretog jeg et casestudie af nissepraksisser hos børnehavebørn i tre institutioner på Vestsjælland. Her undersøgte jeg hvilke traditioner, der var i børnehaverne såvel som i hjemmene. På baggrund heraf forsøgte jeg at afklare, hvad den moderne nisse er for en størrelse, og hvordan den adskiller sig fra sin sagnbundne forfader.

Undersøgelsen viste dels, at nissen ikke bare har træk, som stammer helt tilbage fra sagnene, men også nogle, som er relativt nye; dels at disse nye træk kunne være lige så udbredte, velansete og populære som de gamle. Der var f.eks. stadig mange som satte grød frem til nissen - den nok ældste af alle nissetraditioner - men der var lige så mange af de adspurgte som fortalte, at de havde en nissedør. Nissedøren er en relativt ny opfindelse; den er i al sin enkelthed en lille dør, typisk på størrelse med et A5-ark, som man monterer på væggen. Pointen er så, at nissen bor inde bagved, og at grunden til at døren ikke kan åbnes er, at den er forseglet med magi; det er kun er nissen selv, der kan bruge den.

Denne praksis har ingen rødder i den historiske nisseskikkelse - og heller ikke i de andre væsner, som ligner nissen - men den er dog blevet vel modtaget blandt dem, som holder nisser. Det kan være meget svært at sige noget om, hvor sådanne ritualer kommer fra, men i dette tilfælde er en meget plausibel forklaring, at døren er kommet hertil som fe-dør fra Australien: Nissen er som bekendt et skandinavisk fænomen, og døren var da heller ikke til nisser i sin oprindelige udformning. I Australien findes et firma, som hedder Little Fairydoors, og denne virksomhed, der er omtrent ti år gammel, blev etableret på baggrund af 


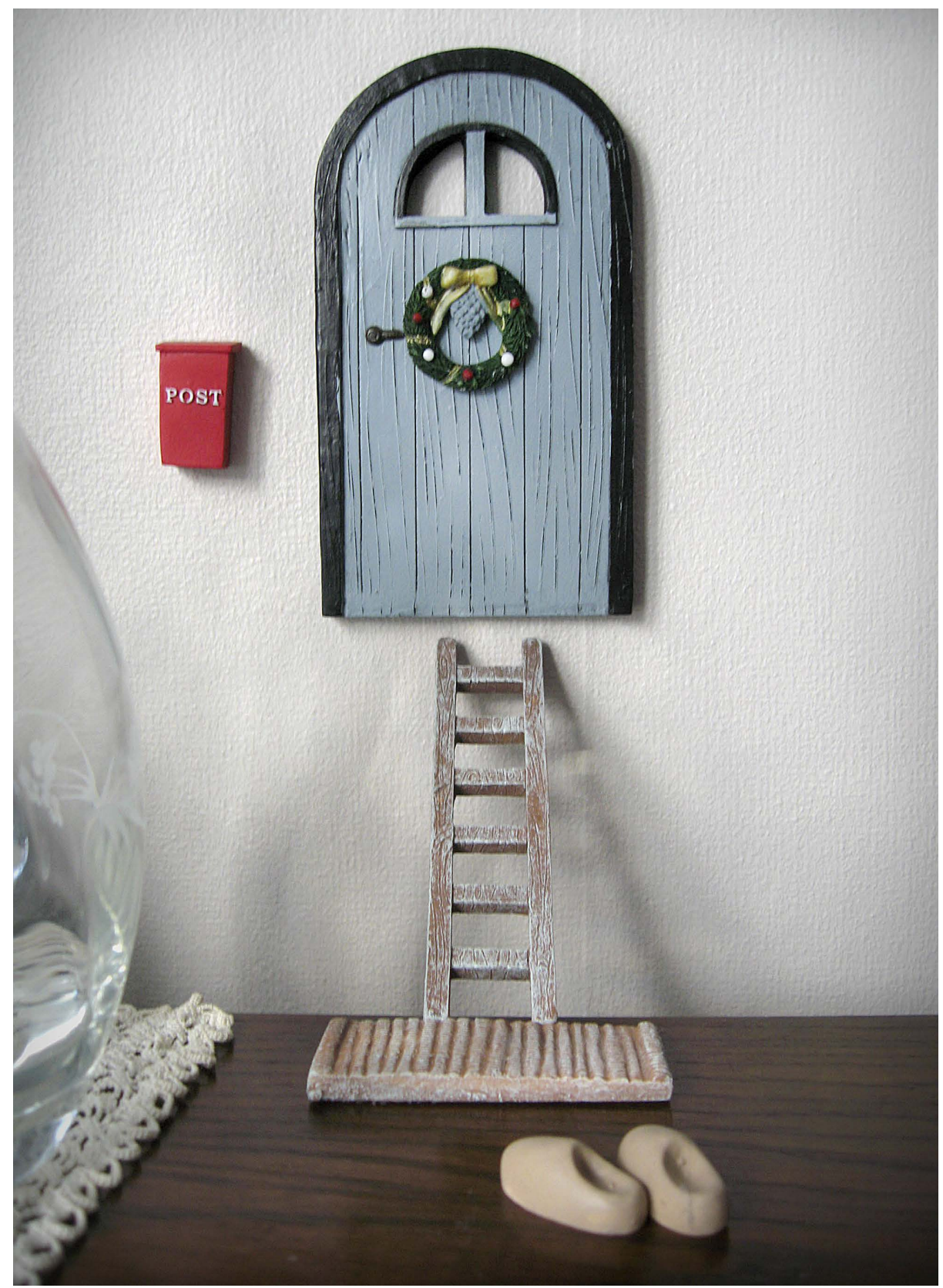

Nissedoren omgives typisk med ting, der viser, at nissen er flyttet ind. Det kan vare alt fra dormätter, postkasser, torresnore og hegn til kalke og trasko. Mange laver selv tilbehør, men det kan også kobes ferdigt hos forhandlere af nissedore. Foto ved forfatteren.

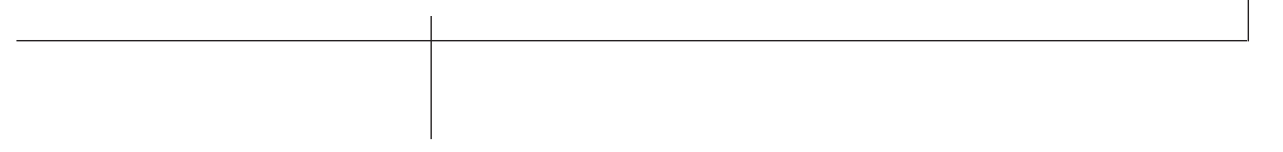


grundlæggerens egne positive oplevelser med fe-døre. Hun havde med succes brugt den til at hjælpe sin datter igennem sit eget svære sygdomsforløb. Ved at skrive breve til sin datter fra feen, som boede bag deres dør, fik hun hjulpet sin datter og bragt magien ind i deres fælles hjem. De fe-døre, som sælges i dag, ville man kunne finde på de fleste pænere dukkehuse; det er en typisk hoveddør. Derudover får man en lille postkasse til breve fra feen. Hvis man køber en fe-dør fra Little Fairydoors får man, ud over dør og postkasse, også en kontrakt med feen klar til underskrivning, samt et glas med fe-støv. ${ }^{3}$ Feen kommer kun ud om natten, og den kan finde på at lægge små opmuntrende breve eller gaver til barnet. Nogle gange kan man se spor efter at feerne har været på spil, f.eks. at legetøjet er flyttet rundt, eller der er sat små fodspor med fe-støv. På disse områder ligner feen til forveksling vores danske nisse. Det er måske ikke så udbredt, at nissen skriver breve til børnene, men de små gaver er ganske ens. Den største forskel på fe-døren og nissedøren er ikke, hvad feen gør, eller hvad barnet gør: Det er derimod det motiv, der ligger bag brugen af døren. Nogle af de ting, fe-døren bliver brugt til, er at hjælpe barnet - f.eks. til at sove i egen seng, med pottetræning eller at flytte. ${ }^{4}$

$\mathrm{E}$ $\mathrm{t}$ af formålene med mit casestudie var at undersøge, hvilke motiver de danske forældre havde, og hvordan disse afspejlede sig i det, familierne gjorde. Her var grunden til at man havde nisser ikke at man kunne bruge dem som pædagogisk værktøj til at hjælpe barnet. I stedet henviste forældrene til at det var en tradition, at det var hyggeligt at have nisser, at det bragte magien ind $\mathrm{i}$ julen og holdt den $\mathrm{i}$ live. Det betyder dog ikke, at den danske nisse savner et pædagogisk aspekt: Især pædagogerne gav udtryk for, at nissen kunne bruges til en masse forskellige ting, og at de tænkte laringsmål med ind i den måde, de 'havde nisse' og 'gjorde nisse' på. Et gennemgående element $\mathrm{i}$ beretningerne var, hvordan nissen kunne bruges i forbindelse med historiefortællinger; ikke blot som noget, man fortalte om, men i historier, hvor børnene selv var en del af fortællingen, selv kunne være med til skabelsen af den, og selv kunne have en fælles erindring om nissen og dens gøren og laden.

\section{Den hyggelige nisse}

Når forældre i undersøgelsen skulle forklare, hvorfor de havde nisser i hjemmet, henviste de som nævnt hyppigst til, at nisser var 'hyggelige'. Det siger meget om vores moderne nisse, at vi før noget andet har den for hyggens skyld. Sagnnissen havde man bestemt ikke for hyggens skyld.

Det kan være meget svært at vurdere, hvorfor mennesker, som levede for 200 år siden, satte grød på loftet. Vi kan ikke vide, om de var fuldkomment overbevist $\mathrm{om}$, at nissen bragte ulykke over gården, hvis ikke de gjorde det. Eller om det i højere grad var noget de gjorde, dels fordi man plejede at gøre sådan, dels fordi det ingen skade var til. Der er imidlertid intet der antyder, at man gjorde det for at hygge sig med sine børn eller børnebørn. I sagnene er det da typisk også med største alvor, at man laver grød til nissen. I sagnenes verden er nissen alle til gavn, hvis blot han får sin grød, og lettere utilregnelig, hvis han ikke gør. 
Hvis vi dermed skal dømme ud fra de fortællinger, der er nedfældet i sagnene, er der stor forskel på motiverne for at have nisser for halvandet hundrede år siden og nu. Hygge er så integreret en del af det nisselige, at en enkelt børnehave til eksempel havde navngivet den ene af deres to nisser - 'Hyggen'. Hyggens partner var 'Drillenissen', og de boede i en kiste, som kom frem til december. Nissens hyggelighed er så naturlig for moderne mennesker, at det kan virke ganske fjernt, at han kan være anderledes. Men hvad vi også ser ved nissedørtraditionen er, at nissen ikke alene er hyggelig, men at den eksisterer på hyggens præmisser. De nissetraditioner, som ikke er hyggelige at lave med børnene, dør gradvist ud og bliver erstattet af andre, der er mere hyggelige. Selvom nissen stadig både giver og driller, $\mathrm{i}$ overensstemmelse med hans natur i sagnene, er dette element også tilpasset den hygge, hvormed vi omgås nissen i dag: Drillerierne er for eksempel farvning af mælken eller ting lagt i skoene; ganske harmløse og noget mindre ubehagelige end de drillerier, som gårdnissen udsatte sin familie for. Samtidig er der i dag ikke større pligtfølelse over for nisserne, end at man dropper dem et år, hvis man ikke magter at bruge tiden på dem.

$\mathrm{P}$ å trods af denne frie omgang med nissen er det ikke kun et spørgsmål om hygge. For børnene kan det være nok så alvorligt, da de ofte tror fuldt og fast på nissen (ifølge deres forældre). For børnene er nissen ikke blot noget vi leger, i hvert fald ikke blandt de børn, der har været inddraget i casestudiet. Her behandles nisser med så megen alvor som børn i alderen 3-6 år generelt udviser. Enhver der kender et barn i denne alder ved, at skellet mellem leg og alvor er flydende for aldersgruppen. Samtidig siger halvdelen af forældrene, at de ville forsøge at overbevise deres barn, hvis det kom til dem med tvivl på nisser. En anden fjerdedel ville svare, at man ikke kan vide det med sikkerhed, men at de måske findes. Forældrene bruger dermed energi på at holde troen i live blandt børnene, ligesom de gør for at skabe troen, for nisserne kommer ikke af sig selv. Nissetraditionerne - hvad enten det er gavegivende nisser eller drillenisser - kommer kun i stand, fordi der er nogle forældre, som ser en værdi deri. De gør det ikke, fordi de selv tro på nisser.

Skønt flertallet holder af det magiske ved at tro på nisser, eller blot ikke afviser at de findes, er der næsten ingen forældre som udtrykker, at de selv tror på nisser. Men hvis forældrene ikke selv tror på nisser, hvorfor går de så op i at deres børn gør? Svaret skal formodentligt findes i det magiske ved at tro på nisser. Når forældrene angiver netop den magiske årsag, er det rimeligt at antage, at de nyder at være en del af børnenes nisseverden. Forældrene nyder, at deres børn tror på nisser - at de kan tro på nisser - og de nyder at være en del af det, når de gør nissen til en levende del af barnets verden i december måned. Heri ligger et dannelsesperspektiv. Der er blandt voksne en opfattelse af, at det er en egenskab ved barndommen, at man kan forundres og tro helhjertet - uden skepsis. Selvom forældrene måske ikke mener, at de selv tror på nisser, er de alligevel med på troen; det er ligefrem forældrene, som skaber og opretholder den. 
$\mathrm{N}$ issen har altid været en spejling af de mennesker, som den levede hos. Det gælder både for sagnene, hvor nissen var en del af gårdens folk ligesom karlene og pigerne. Det gælder for den litterære julenisse, som afspejler borgerskabets idealer og bliver en naturlig del af dets jul. Endelig gælder det også den moderne nisse, som tager udgangspunkt i det hyggelige og magiske.

Når vi følger nissens historie, følger vi dermed også danskernes historie. Sagnnissen forsvandt sammen med den gamle landbrugsform. H.C. Andersens poesielskende nisse veg til side, da den kulturelle tone ændrede sig. Den moderne nisse ændrer sig også år for år, i takt med at nye familier finder deres måde at have nisser på, og nye mærkelige traditioner som nissedøren bliver velkendte og udbredte. Nissen er dermed ikke blot noget børn leger. For uanset om folk tror på nisser, er det stadig udbredt at gøre noget med nisser. Heri har nisserne en realitet, der ikke kan fornægtes, og de er både en interessant og signifikant del af dansk kultur.

\section{Noter}

1 Hans Lauritsøn: Sielebog. Prentet i Kjøbenhaffn 1587. Det Kgl. Bibliotek: Opt af S. Thoby 1965.

2 J.M. Thiele, Danske Folkesagn v. 2, 1819 23.

$3<$ <ww.littlefairydoor.com/content/4about-us $>$.

$4<$ <ww.littlefairydoor.com>. 